\title{
The Use and Reuse of Julius Caesar’s Religious Résumé on Imperatorial Coinage*
}

\author{
Gaius Stern \\ University of California, Berkeley, USA
}

\begin{abstract}
Soon after Roman mint masters began issuing the silver denarius (traditional date 187 B.C.), they discovered that they could employ coinage as newspapers and PR by individualizing the imagery on each side of the coin with references to their ancestry, current events, and/or their religious offices to increase their name recognition in order to win votes. It should come as no surprise that the Divine Julius ordered his mint masters to issue coinage that advertised all of the above features to circulate his good reputation in what our modern political scientists would call propaganda. After Julius' enemies began to attack his reputation, some of his partisans boasted of their closeness to him on coinage by recycling specific coin images. What is surprising is how these partisans adopted the exact imagery Julius had used to advertise his own religious résumé on their coinage, even though these religious images could not and did not apply to them specifically. Apparently, Julius’ religious résumé no longer demonstrated a religious portfolio, but had transformed into a badge of partisanship, however thinly it applied, so that the religious symbols themselves retained only the function of an association with Julius without their original and intrinsic meaning.
\end{abstract}

Keywords: Roman history, Roman religion, Roman coinage, Julius Caesar, Augustus, lituus, simpulum, numismatics, Second Triumvirate

\section{Introduction}

Under the Republic, the appearance of religious implements on coinage advertised the religious credentials of the mint-master or his patron. Two of Julius Caesar's coins illustrated religious implements for this exact goal, namely the elephant coin and the post-Thapsus (46 B.C.) AUGUR PONT MAX coin (see Figures 1 and 2). During the Era of the Second Triumvirate, especially 43-40 B.C., certain Caesarian partisans circulated coins with the exact same reverses as Julius Caesar, not exclusively to advertise themselves as priests, but because they were advertising their loyalty to and/or claiming leadership of the Caesarean faction (see Figures 3 and 4), and although sometimes these images vary on later coins, the AUGUR PONT MAX reverse reappears exactly, albeit with a new meaning to announce that the emperor had become the Pontifex Maximus.

\footnotetext{
* This paper was originally presented at the Classical Association of the Pacific Northwest, 15-16 March 2013, at the University of Oregon at Eugene. Except for Figures 5, 6, 8, 9, 10, 14, 16, 17, 18, 19, 27, 29, 30, 31, 33, 34, 36, and 38, which are the author's own, the other images were generously provided by David Freeman (Retrieved from www.wildwinds.com).

Gaius Stern, Ph.D., lecturer in Roman Material Culture, Department of History of Art, University of California.
} 


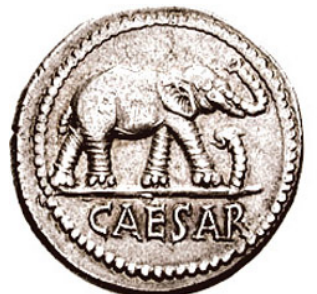

Figure 1. Elephant denarius of Julius 49/48 B.C.
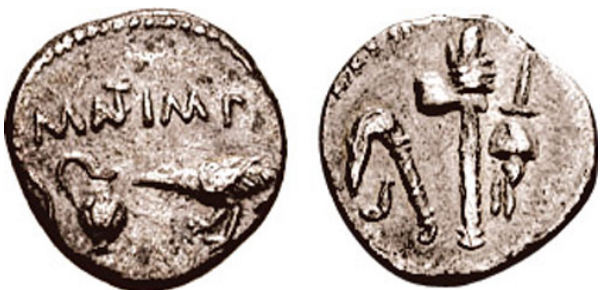

Figure 3. Lepidus/Antony denarius, 43 B.C.

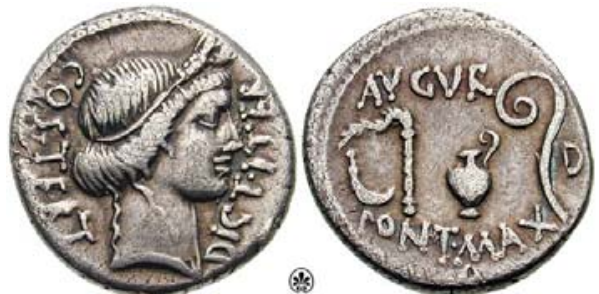

Figure 2. AUGUR PONT MAX denarius, 46 B.C.

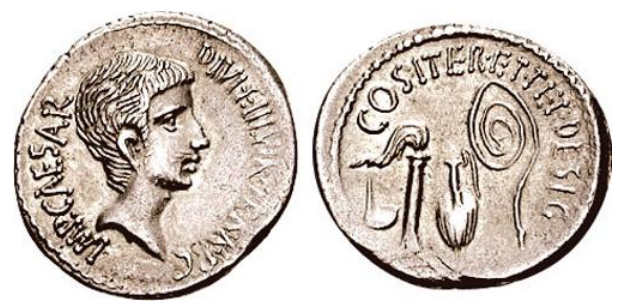

Figure 4. Caesar Octavian denarius, 37 B.C.

As a rule, broken first by Julius himself in 46 B.C., Roman mint masters did not put portraits of living people on coinage. Every other form of self-promotion was permitted, so long as the line of personal portraiture was not crossed. Devising new images of self-promotion on coinage became a game for the mint master whereby references to famous ancestors, divine heritage, and every other exploitable advantage were permitted, eventually even including stick figure representation of oneself. Because the Roman denarius was the size of a dime, artwork could only express so much on a small field. Many symbols were engaged to announce messages that were common, every day features of Roman life and immediately recognizable to every citizen. However, some of them are not as easy for us to recognize and therefore require explanation.

\section{Republican Use of Religious Implements on Coinage}

During the Republic, the top three colleges of the Roman religion were the Pontifical College, the Augural College, and the College of the XVviri: the Quindecimviri Sacris Facundis (Lewis, 1955, p. 92). ${ }^{1}$ Each college used special, unique immediately identifiable implements. The top four priests of the Roman religion, the Pontifex Maximus and the priests of Jupiter, Mars, and Romulus respectively, belonged to the Pontifical College. They were immediately recognizable in public when performing their duties from both their clothing and the objects they carried (see Figure 5). The Pontifex Maximus had a special religious implement called an aspergillus, essentially a holy water sprinkler. The next three ranking priests had to wear a special double toga and a special skullcap at religious ceremonies, called a galerus with a spike, called an apex, well-known from the Ara Pacis. In addition, the priest of Jupiter, the Flamen Dialis, was attended by the early version of an altar boy, called a camillus, who carried his ceremonial axe. The other members of the Pontifical College all carried a ladle called a simpulum and/or a special jug (guttes). The Augures had a special wand called a lituus and a jug called a capis. The Quindecimviri, as priests of Apollo, each had a special tripod, which was used as they are standard religious symbol. All of the symbols occasionally appear on coinage in order to advertise a major priesthood, although the mint master himself did not necessarily have to occupy the post. Mint masters perfectly willingly advertised the holiness and integrity of an ancestor who held a major religious post with the idea that voters could trust the mint

\footnotetext{
${ }^{1}$ A fourth college, the Septemviri Epulones, was promoted to senior status under Augustus in 16 B.C.
} 
master and confidently vote for him in his future political campaigns, based on the sterling character of his ancestor. Descent from a great Roman war hero or a man renowned for his piety applied voter appeal to coinage.

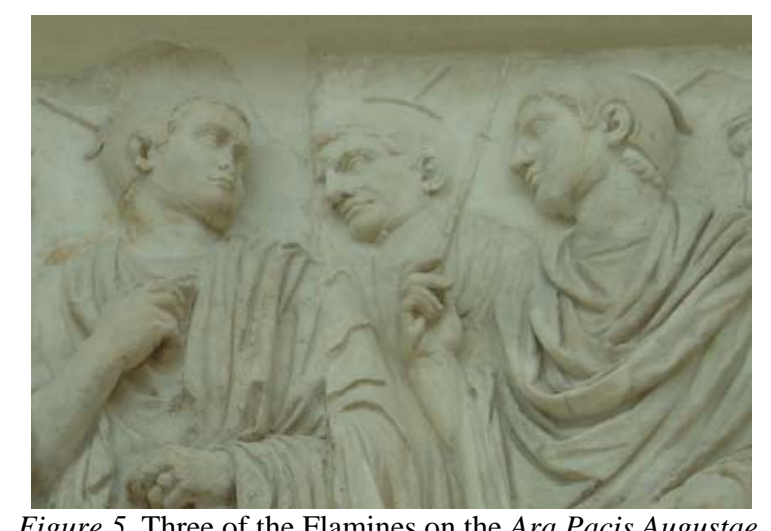

Several examples illustrate the culture these coins fed and augmented, occasionally leading to conversations between the mint masters, a few of which famously turned ugly. In 134 B.C., Ti. Minucius Augurinus released the denarius (see Figure 6) which has a very traditional obverse-Roma, but a novel reverse of two togate figures, one holding a simpulum, the other a lituus, standing by a column in a pose of worship. Although they are stick figures, they represent Minucius and his brother, rather than two random worshipers. The message clearly advertizes the pietas of the mint master and hence his and his brother's qualification for high office.

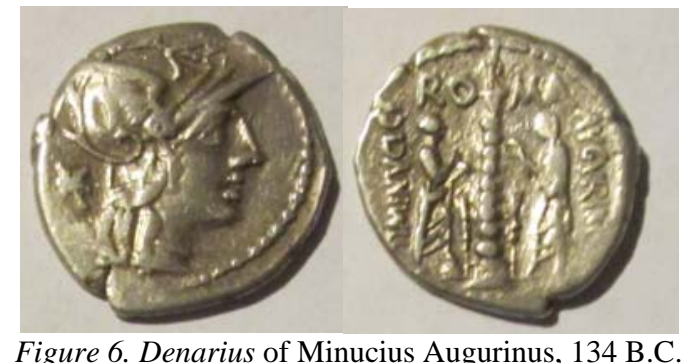

Similarly, ca 126 B.C., Fabius Pictor released a denarius (see Figure 7) whose reverse shows a seated figure beside a shield and the galerus with the apex of a flamen, apparently referring to an ancestor who held one of the top priesthoods. In this case Fabius solicits votes based on his family's military and the sacral accomplishments, a pattern he can be trusted to uphold. A denarius of L. Valerius Flaccus, 108-107 B.C., shows the winged goddess Victory (Nike) on the obverse. This reverse, like that of Fabius, shows a crowded scene with multiple images (see Figure 8). The god Mars dominates the center between a head of wheat and again the galerus and apex of a flamen, apparently commemorating an ancestor of the mint master. His name also appears in small letters.

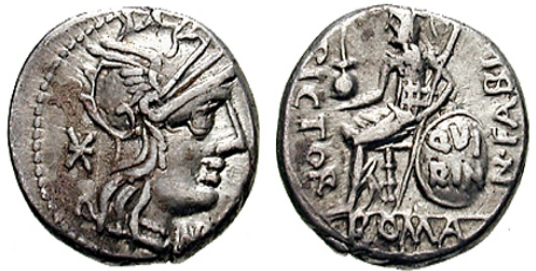

Figure 7. Denarius of Fabius Pictor, 126 B.C.

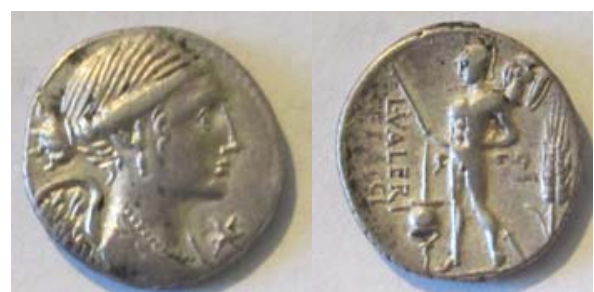

Figure 8. Denarius of Valerius Flaccus, 108-107 B.C. 
In 69 B.C., friends of P. Sulpicius Galba released a denarius of a veiled Vesta on the obverse and a secespita (sacrificial knife), simpulum, and securis (axe) on the reverse, which alludes both to his ancestors and to him (see Figure 9). The knife refers to an unknown priesthood (it also appears on a coin of Brutus and Lentulus (see Figure 22)). The axe certainly refers to an ancestral Flamen Dialis. The simpulum refers to Galba himself, who was a Pontifex. ${ }^{2}$ The family had entered the Pontifical College at least as early as 203 B.C. when Ser. Sulpicius Galba was elected pontifex to succeed Q. Fabius Maximus. ${ }^{3}$ Although backed by Julius, Galba later lost the consular election in 64 to Cicero and C. Antony. Later in anger, he turned against Julius when passed over for a consulship. ${ }^{4}$ He joined the conspiracy led by Brutus and Cassius, for which he was sentenced to death under the Lex Pedia. $^{5}$

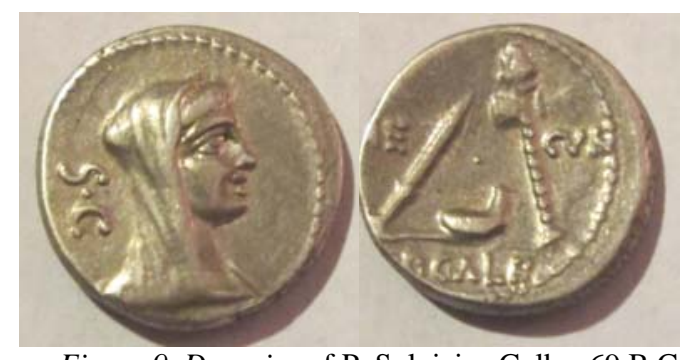

Figure 9. Denarius of P. Sulpicius Galba, 69 B.C.

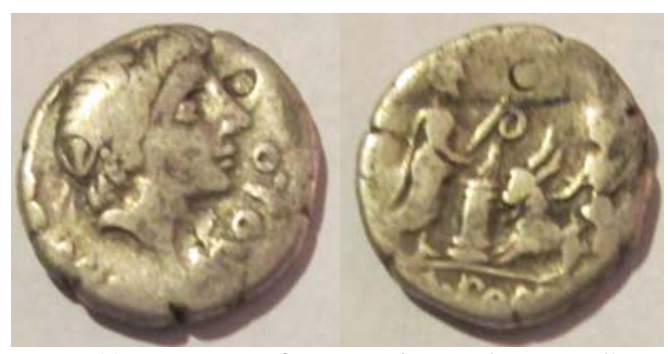

Figure 10. Denarius of Pomponius Molo, 97 B.C.

As a matter of fact, one finds the symbol of the Augural College, the lituus, far more often than the simpulum on coins. A fairly early example was minted in 97 B.C. by Pomponius Molo (see Figure 10), whose denarius shows his ancestor, king Numa Pompilius, performing a sacrifice and holding a lituus. Molo is one of few mint masters to employ an image of a king on money to persuade voters of his worthiness. Most of the kings had an odious recollection to voters.

Far more common is the example of C. Servilius Vatia in 127 B.C., who placed a lituus on the obverse behind the head of Roma, referring to himself or an ancestor to persuade voters of his worthiness (see Figure 11). His son minted an extremely similar coin, substituting Apollo for Roma (see Figure 12). Many other ambitious politicians added the lituus as a self reference on the obverse, even if they apparently blurred the image by placing their own lituus beside a portrait of an ancestor or a god (see Figures 12-16).

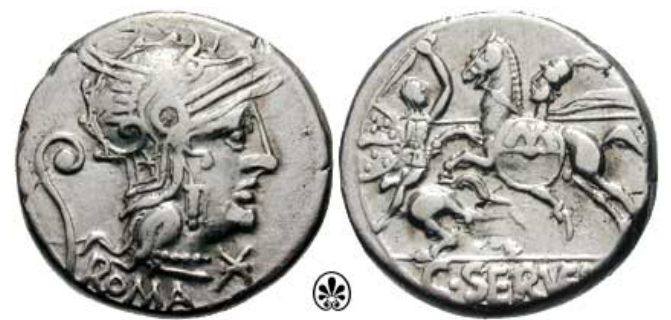

Figure 11. Denarius of Servilius Vatia, 127 B.C.

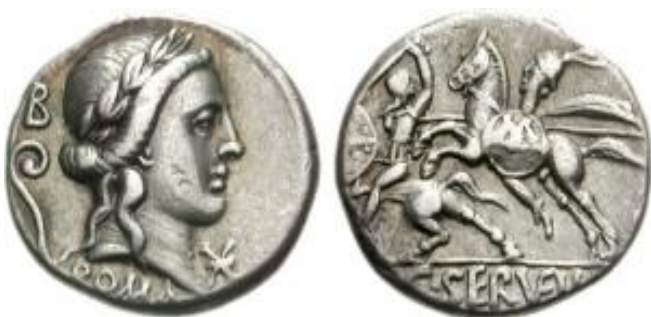

Figure 12. Denarius of Servilius Vatia, 82 B.C.

\footnotetext{
${ }^{2}$ Cic. De Har. Resp. 6.12; Macr. Sat. 3.13.11. Galba was curile aedile in 69 (when Cicero was a plebeian aedile). It is most likely considering the listing of his own magistracy as aedile that it refers to himself.

${ }^{3}$ Liv. 30.26.10. Strangely, C. Sulpicius Galba was elected Pontifex to succeed Manlius Torquatus in 202 B.C., Liv. 30.39.6, although two members of the same family should not sit in the same college. See Szemlar (1972) for a thorough study on the occupants and dates of the religious offices in the Republic.

4 Suet. Galba 3. C. f. Sen. De Ira 3.31.2.

${ }^{5}$ Cic. Ad. Att. 1.1; Suet. Galba 3.
} 


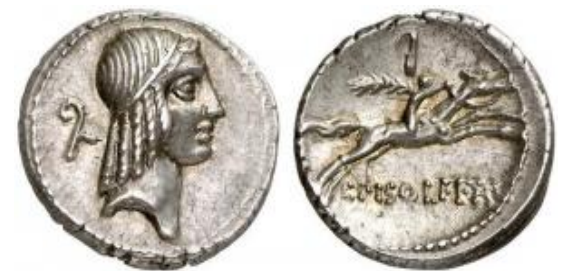

Figure 13. Denarius of Calpurnius Piso, 90 B.C.

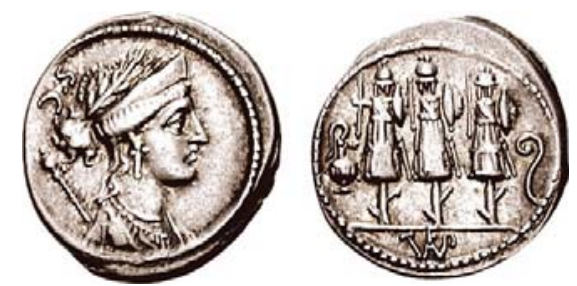

Figure 15. Denarius of Faustus Sulla, 56 B.C.

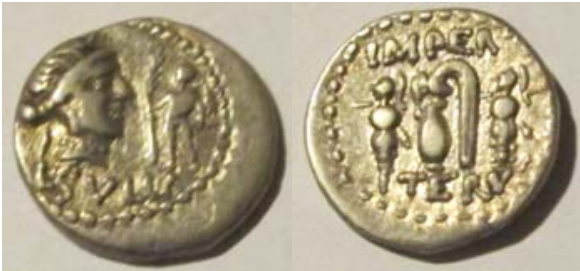

Figure 14. Denarius of Sulla, 84-83 B.C.

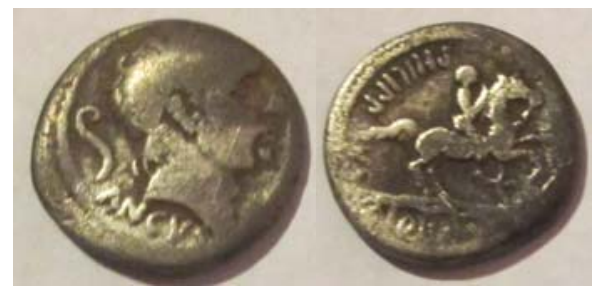

Figure 16. Denarius of L. Marcius Philippus, 56 B.C.

A large issue of denarii, issued by Calpurnius Piso in 90 B.C. shows Apollo on the obverse and a rider (probably a desultor) in a horserace on the reverse (see Figure 13). A younger kinsman rereleased very similar series a generation later. The imagery varies slightly from issue to issue, but on one issue the lituus appears behind the head of Apollo, a god linked to divination.

Sulla also belongs on the long list of politicians who put a lituus on his coin to show he is an Augur. In 84/84 B.C., he advertized his victories with a denarius that includes two religious symbols, a jug (capis) and the lituus (Stewart, 1997, pp. 107-189) (see Figure 14). ${ }^{6}$ The jug might indicate he was a Pontifex, as some scholars believe. In 56 B.C., mint masters loyal to his son issued the same two symbols on the reverse to evoke Sulla's priesthoods and to express the son's ambitions (see Figure 15).

In that same year, 56 B.C., the step-brother to the future emperor Augustus, L. Marcius Philippus, released a denarius of his alleged ancestor, king Ancus Marcius on the obverse and the Aqua Marcia on the reverse (see Figure 16), while his father was consul. The family issued several other denarii with Ancus or both Ancus and Numa on the obverse. The lituus behind the head of Ancus indicates the priesthood the family currently enjoyed (held by the father of the moneyer). The moneyer later held a suffect consulship in 38 B.C.

Also in the 80s, the future Pontifex Maximus Q. Caecilius Metellus Pius minted a denarius decorated with a jug and lituus (see Figure 17). Metellus Pius was certainly never an Augur, so the symbols either refer to ancestors or constitute a partisan emblem for the Optimates faction to which Sulla and Metellus Pius belonged, based on the Sullan precedent (See Figure 13). ${ }^{7}$ The imagery of Pietas and the stork (a bird that Romans thought mated for life) refer to his efforts to recall from exile his father.

In this numismatic atmosphere of advertisement of one's own pietas and worthiness for office, we do not find it all surprising that the Divine Julius vaunted himself in a very large issue upon the outbreak of the Civil War in 49. Furthermore, because Julius never held the post of triumvir of the mint, this was his first opportunity to produce coinage to advertising himself and his agenda to the Roman world.

\footnotetext{
${ }^{6}$ Stewart, (1997), says Sulla was the first to use both to indicate that he was simultaneously a Pontifex and an Augur, contra L. R. Taylor (1944); Frier (1967; 1969); Fears (1974); A. Keaveny (1982), and T. Martin (1989).

7 See also how his younger contemporary and rival, Pompey the Great similarly issued an aureus that shows the jug and lituus to coincide with one of his triumphs. We know he was an augur, so one can attribute both symbols to his priesthood, or as in the case of Metellus Pius, one may regard the double symbols as a badge of partisanship with the Optimates of Sulla.
} 


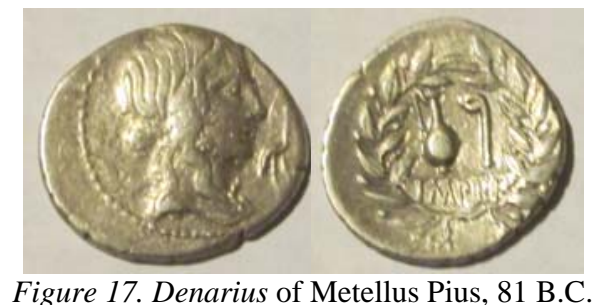

\section{Julius Caesar'S Use of Religious Imagery on Coinage}

In 49 and possibly into 48 Julius released the famous elephant denarius (see Figures 1 \& 18). The reverse presents Julius' religious résumé, and hence his pietas. The first pair of religious symbols refers to Julius' current post as Pontifex Maximus: the simpulum and aspergillus. Julius had been elected Pontifex Maximus in 63 over bitter opposition from the Optimates through much bribery of voters. The second pair, the axe (securis) and galerus with its apex, refers to Julius' youthful, brief term as Flamen Dialis, which was cut short during the civil war of the 80s when Sulla had Julius defrocked and put a price on his head. The mint master included the symbol of priesthood taken from Julius, a post by 49 B.C. vacant for over 30 years, perhaps as a reminder that Julius' enemies had wrongly and impiously stripped him of it (Stern, 2003, pp. 293-297). ${ }^{8}$ The combination of religious symbols asserts a moral high ground, for Julius was the only man in history to hold the two highest individual posts in the Roman religion (but not simultaneously). Together these four religious symbols became a coat of arms for the Caesarians, which as we shall see, later partisans embraced to express their loyalty or leadership.

The elephant has received far more attention, and many scholars interpret it as a symbol of Roman power. However, elephants are more associated with Africa, and especially Carthage, so it is odd to see it applied as an expression of Roman might. Only the family of the Caecilii Metelli used the elephant on Roman coinage, and they did so because an ancestor was the first to capture elephants (during the First Punic War). One of my students, Aaron Parker, suggests that the elephant may not be a symbol of power of the Roman army or a real elephant, but a more complex symbol of the surrender of the enemy. The elephant represents how Julius' conquest of Gaul in the 50s forced the Gauls to surrender all means of making war: ships, weapons, and elephants. Vercingetorix did not have any elephants, but Romans understood it as a metaphor for armaments, from previous conquests. The elephant and the pipe (often mistaken for a snake) in front of it are symbols of the Gallic surrender that resulted in complete Roman victory. ${ }^{9}$

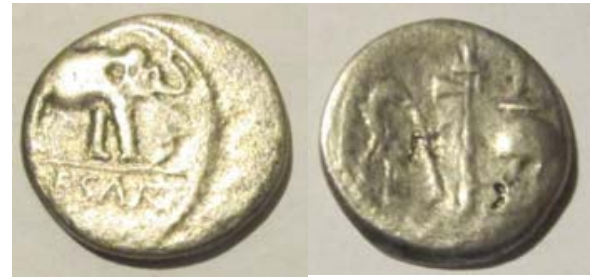

Figure 18. Elephant denarius of Julius, 48 B.C.

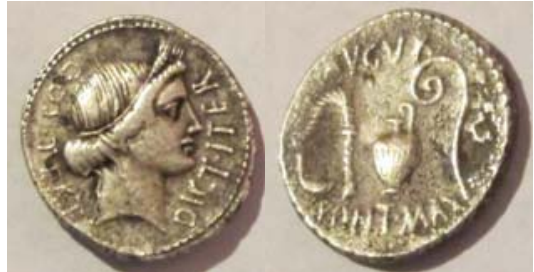

Figure 19. Denarius, AUGUR PONT MAX, 46 B.C.

\footnotetext{
${ }^{8}$ The post remained vacant for ca. 75 years until approximately 15 B.C., when Augustus pressured the aged Lepidus to choose a new priest of Jupiter, Tac. Ann. 3.58.

9 John Jencek has shown me that the item is certainly not a snake, but a Gallic pipe. A coin of Brutus Albinus also shows the same pipes as tokens of surrender.
} 
The second denarius (see Figure 19) was minted after the battle of Thapsus. The obverse bears either Ceres or Venus. The reverse bears an updated résumé that a number of his partisans would duplicate. Upon winning Thapsus, Julius annexed a post as Augur so that he could occupy a seat in each of the top two colleges. The coin shows the simpulum and the aspergillum to represent his post as Pontifex Maximus and the capis and lituus to represent his new post as augur. This reverse image was later revived by Vespasian, and used by several subsequent emperors (see Figure 37).

\section{Imperatores in the Aftermath of the Ides of March}

After the assassination of Julius, the number of religious symbols on coinage proliferated. Anyone who could control a mint issued coins of self-glorification, sometimes with portraiture, and often times with expressions of pietas by advertising their own priesthood. Antony enthusiastically applied both tactics. Immediately after the battle of Mutina on 14 April 43 B.C., he and Lepidus united against the young Caesar and the Senate, and they began to mint coins. A denarius minted in 43 advertises their numerous religious offices (see Figure 19). The obverse shows Antony's augurship in triplicate with a lituus, a jug, and a bird. Remarkably, the reverse, which should advertise Lepidus' post as Pontifex Maximus instead duplicates the reverse of Julius' elephant coin (see Figure 17). The first two symbols, of course, could apply to Lepidus perfectly, but the latter pair can only express partisan loyalty to the memory of Julius, and proclaim Lepidus' leadership of the Caesarians (against the upstart young Caesar!). However, very soon an invitation from the young Caesar brought the trio together to form the Second Triumvirate against their common enemies, namely the Senate and the assassins. Their coinage celebrates this alliance by placing any two of the three triumvirs on a coin. Following the Philippi campaign in 42 B.C., Antony’s coinage regularly shows a lituus, marking him an Augur. ${ }^{10}$

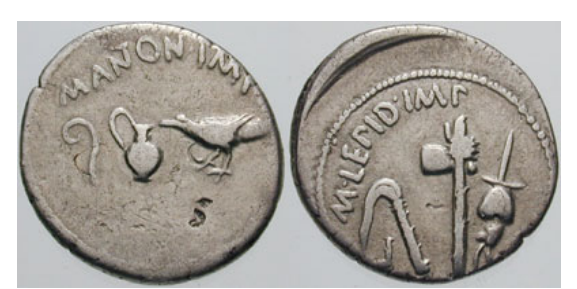

Figure 20. Denarius, Antony and Lepidus, 43 B.C.

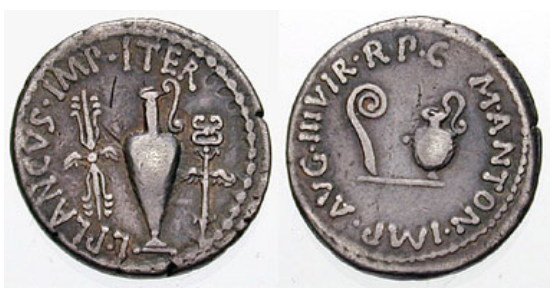

Figure 21. Denarius, Antony and Plancus, 42 B.C.

Religious symbols appear on the coins of other imperatores, as well. One example, minted under Antony's ally, Munatius Plancus (see Figure 21), carries a thunderbolt, a jug, and a caduceus on one side to illustrate divine favor and power, sanctity, and prosperity. Its reverse bears two symbols of the Augural College in reference to Antony's and/or Plancus' priesthood.

The presence of religious symbols on coinage proliferated swiftly under every possible commander who can stake a claim. In reply to the Caesarians Brutus, Cassius, and Lentulus Spinther began to produce their own coins with multiple religious symbols to advertise their pietas. Lentulus and Brutus released reply to Lepidus and Antony that shows Lentulus as a Augur by means of the jug and lituus and boasts three different priesthoods of

\footnotetext{
${ }^{10}$ Antony was nominated to be the Flamen Iulialis in 44, and thus also was a member of the Pontifical College, but he was not inaugurated until 41/40. Antony must have expected to inherit power after Julius, as the son of a Julia, Julius' colleague and right hand man in 44, and now his priest (and later he married Julius' great-niece). He surely resented Julius's failure to prefer him. A very similar relationship developed between Tiberius and Augustus.
} 
prior and current Junii Bruti with the axe, simpulum (Brutus himself), and knife (see Figure 22). Another denarius (see Figure 23) shows a tripod for Cassius and the Augural jug and lituus for Lentulus to prove their religious credentials against the Caesarians. Cassius is now a victorious general, IMP (erator). A third coin (see Figure 24), minted by the pro-quaestor Sestius under Brutus, uses a tripod for Cassius the XVvir and a simpulum for either Brutus or Lentulus_-both Pontifices-along with an ancestor's flamen's axe for Brutus, as if they also were a triumvirate and alternated images on their coinage in reply to the Second Triumvirate. Lentulus apparently claimed the third leadership position among the assassins after the death of December Brutus Albinus. Of course, the Caesareans continued to claim the religious high ground, and they used spoils to win support. The priesthoods ranked among the best spoils of war, so the Second Triumvirate now distributed them to loyal followers and new friends to fill the vacancies created by dead enemies. Naturally, several followers advertised these religious posts on coinage. A most remarkable issue was released in Osca, Spain in 40 B.C. by Domitius Calvinus (cos. 53, 40), partly as an expression of loyalty to Julius and partly as self-promotion. Like the denarius of Lepidus, his issue duplicates the reverse of Julius' elephant coin with its four religious symbols, three of which represent posts Domitius Calvinus never occupied. ${ }^{11}$ This coin (see Figure 25) serves several purposes at once. It vaunts Domitius Calvinus as a loyal follower of the late dictator (now a God). As it circulated in an area where Julius had many clients and a repeated presence, it emphasized the association of Domitius Calvinus with Julius. Thereby, the coin advances his claim to play a greater leadership role in the state. However, if he believed his political power was genuine and could elevate his political authority to equal the triumvirs, his ambitions did not pan out.
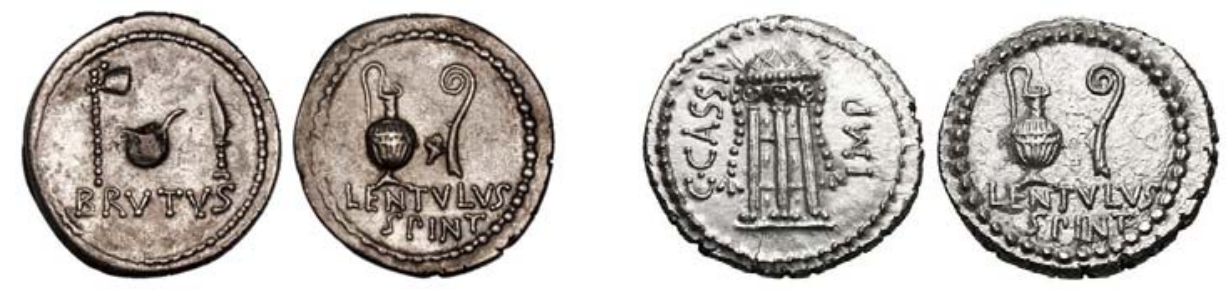

Figure 22. Denarius, Brutus and Lentulus, 43/42 B.C. Figure 23. Denarius of Cassius, 43/42 B.C.

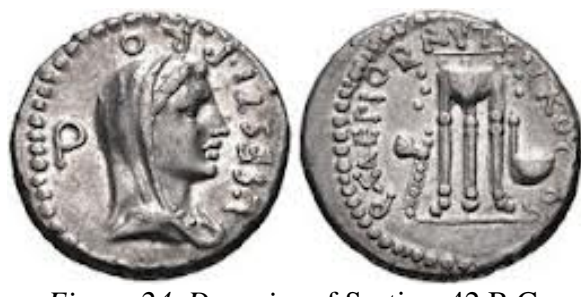

Figure 24. Denarius of Sestius, 42 B.C.

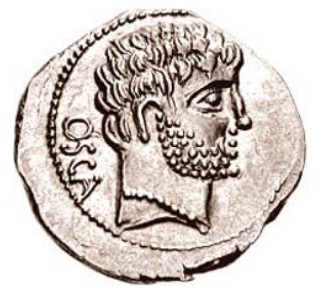

Figure 25. Denarius of Domitius Calvinus, 40 B.C.

\section{Coinage of the Young Caesar Bearing Religious Imagery}

Starting in 43, coins advertised Antony’s Augurship and Lepidus’ post as Pontifex Maximus. The person we should most expect to employ Julius' religious résumé as his own emblem was surprisingly restrained: the Young Caesar. Although he had received a Pontifical seat in 47 and an Augurship by 37, he rarely applied

\footnotetext{
${ }^{11}$ Domitius Calvinus held seat in the Pontifical College, ILS $42=$ CIL 6.1301. Aside from Lepidus he was the only man alive who held two consulships. The young Caesar held two brief consulships in 43 and 37.
} 
religious imagery to his coinage. Instead he repeatedly emphasized his connection to the Divine Julius as DIVI FILIUS (son of the god), and in later life we can see that he celebrated his multiple priesthoods. ${ }^{12}$ Only once before 30 B.C., when he joined two priestly colleges, did he release denarii that recount his religious résumé, a triple issue, dated by Sear to 37 (Sear, 1995, pp. 190-191; Lewis, 1955, p. 42). ${ }^{13}$ The first denarius displays a tripod to advertize his entry into the College of the XVviri (see Figure 26). ${ }^{14}$ The legend around the tripod reads "Caesar, consul in the future a second and third time" inside a wreath. The second denarius, employing the same imagery of Julius' AUGUR PONT MAX denarius (see Figure 19), marks his entry into the Augural College with the simpulum, aspergillum, capis, and lituus, even though only three of the symbols can apply to the Young Caesar, who was not yet Pontifex Maximus (a post he thought he deserved). The obverse has no portrait, only the same words as the first denarius. The third denarius repeats the legend and reverse of the second and includes a portrait (see Figures 4 and 27). This triple issue was his only such release of coins with multiple religious symbols for nearly 20 years, and when the Roman mint did release coins advertising Augustus’ religious résumé in 16 B.C., a new arrangement proclaimed a new message.

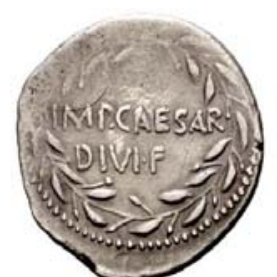

Figure 26. Tripod denarius of Imp Caesar, 37 B.C.

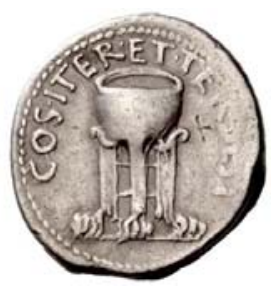

Even while his numerous rivals were trying to elevate their status with religious and political appeals on coins (including Sextus Pompey), Imperator Caesar, as he called himself, displayed only occasional religious assertions. Like Antony, he issued a few early coins that show a lituus behind his head, such as on the AEGYPTO CAPTA denarius, partly to link him to his favorite god, Apollo (see Figure 28). After 29, once his last rivals had been cleared aside, Augustus—as he was now known—continued only intermittently to reuse the religious reverses of his divine father and never did so to elevate his religious status above others. Augustus could play the religious card only so far while another man held the coveted post of Pontifex Maximus.

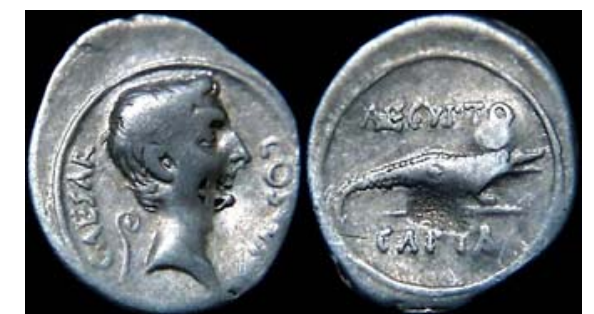

Figure 28. Aegypto Capta/crocodile denarius, 30 B.C.

Julius and Augustus used the same religious imagery on coins to say very different things. Whereas Julius advertised his religious credentials on the elephant coin, and announced his Augurship on the Venus coin to rise

\footnotetext{
12 Res Gestae 7, 10.

${ }^{13}$ Lewis (1955) had dated the Augurship of Augustus between 43-40 B.C., citing Grueber 2.398, 404, 491, 493. Sear's later date is to be preferred.

14 As a devotee of Apollo, the young Caesar certainly wanted to join his priesthood as early as possible.
} 
above his rivals, the Young Caesar engaged these images within a larger, multifarious set of numismatic images to associate himself with his father, not as a personal résumé. Other coins show the both of them on the obverse, or place one on each side of the denarius, the Julian comet, statues of Julius, or the temple of Julius. He alone enjoyed a kinship with the Divine Julius, an advantage that topped any of Antony, Lepidus, or Domitius Calvinus, no matter how valiantly they tried to associate themselves with the Divine Julius. Their numismatic expressions of loyalty persuaded few when the public saw them oppose the one man with the name Caesar. The family connection and the name conquered all.

\section{Augustus' Use of Religious Implements on Coinage During the Principate}

Oddly enough, the Spanish mint produced several issues whose obverse bears the head of Augustus and whose reverse bears Julius' religious résumé from the elephant denarius, long after its original message was obsolete. Augustus's portrait on the obverse was by this time standard. These coins apparently mark anniversaries, such as the 25th year after the Ides of March, thus in 19 B.C. Another possibility for a later issue was the 75th anniversary of the nomination of Julius as Flamen Dialis, thus ca. 11 B.C., or the 50th anniversary of his election as Pontifex Maximus, thus 13 B.C. (although the latter two might be of little importance in the provinces). An excellent example of this is the large copper coin from Novo Carthago minted by Varius Rufus and Julius Pollio (see Figure 29). The same images reappeared on multiple issues of the smaller value aes.

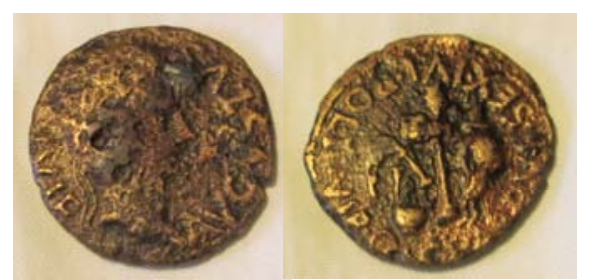

Figure 29. Novo Carthago mint, symbols of Julius.

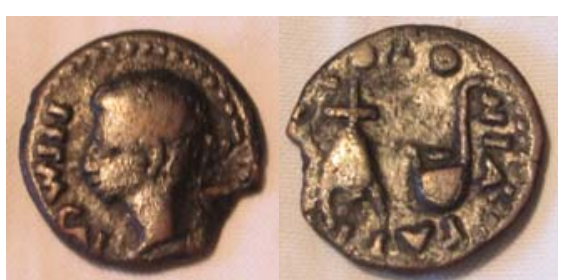

Figure 30. Colonia Patricia aes, galerus simpulum.

A different bronze aes, from Colonia Patricia, bears on the reverse the galerus with apex and the simpulum (Sear dates it 19/18 to 2 B.C.) (see Figure 30). The galerus with apex refers to a lesser priesthood of Augustus; he was also a fetialis. The simpulum of course refers to his Pontificate.

Another bronze aes, also from Colonia Patricia, shows a poor portrait of Augustus and the simpulum, jug, and the lituus (see Figure 31). Three religious implements from Julius' elephant coin reappear, but the presence above the jug of a patera (dish), which represents the VIIviri, shows that this coin celebrates Augustus, who by 12 B.C. held all of the represented priesthoods. The simpulum was deleted as redundant, now that Augustus is Pontifex Maximus. A dupondius issued in 12 B.C. from Ebora (Portugal) verifies this interpretation (see Figure 32). ${ }^{15}$

Innovation in the colonial mints followed in the more important Roman mint, which had a greater ability to circulate messages. An important denarius from 16 B.C. celebrates the occasion of Augustus obtaining a seat within the college of the VIIviri (see Figure 33). The coin depicts one symbol for each of the top four religious colleges: simpulum, lituus, tripod, and patera. Three years later in 13 B.C. a second release with an exceedingly

\footnotetext{
${ }^{15}$ An earlier coin from the Alexandrian mint ca. 19 B.C. also mixes the symbols of both of Julius' coins onto an Augustan era bronze aes. The obverse bears a portrait of Augustus; the reverse the letters KAICAR and the simpulum, jug, lituus and axe (Retrieved from http://wildwinds.com/coins/sear5/s1716.html\#milne_07).
} 
similar reverse was issued, probably because Agrippa had also joined the top four colleges (see Figure 34). Alternately it serves to remind voters of Augustus' sacral qualifications for the vacant post of Pontifex Maximus shortly after the death of Lepidus in 13. Just as Julius had his mint masters advertize his sacral greatness in 46, mint masters in Rome likewise celebrated Augustus' sacral greatness in 16 and perhaps that of Agrippa or Augustus in 13. The coin might serve to draft Augustus for Pontifex Maximus.

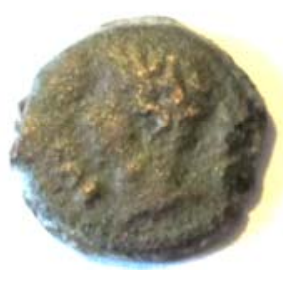

Figure 31. Aes, Colonia Patricia mint, ca. 12 B.C.

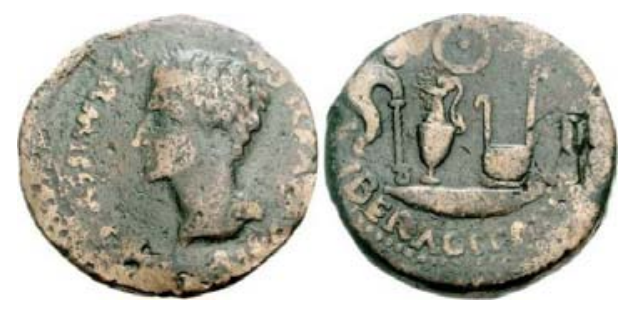

Figure 32. Ebora mint dupondius, ca. 12 B.C.

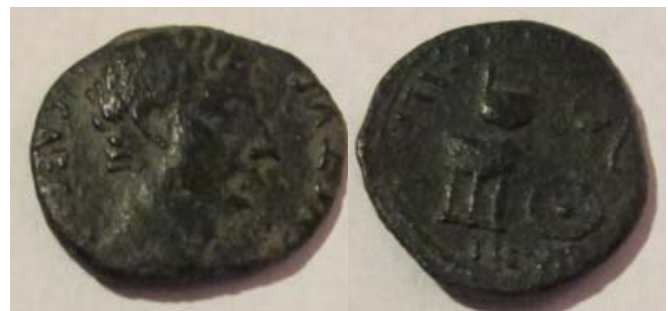

Figure 33. Denarius showing multiple priesthoods, 16 B.C. Figure 34. Denarius, multiple priesthoods 13 B.C.

The mint produced in two successive years, 9 and 8 B.C., new issues of multiple religious symbols. In 9, the three mint masters Aelius Lamia, Silius, and Annius released a quadrans with the unmistakable symbols of the Augural and Pontifical colleges, followed in the next year by a near identical release from Statilius Taurus, Livinius Regulus, and Claudius Pulcher (see Figure 35). The low value coins circulated the message to a much wider audience. It likely serves to draft Augustus' sons Gaius and Lucius to membership within the top religious colleges when vacancies may occur. Both princes soon obtained priesthoods, a fact well attested from both epigraphy and textual evidence, and especially from a prolific issue of aureii and denarii in 2 B.C. that place the lituus and simpulum over the heads of Gaius and Lucius( see Figure 36).

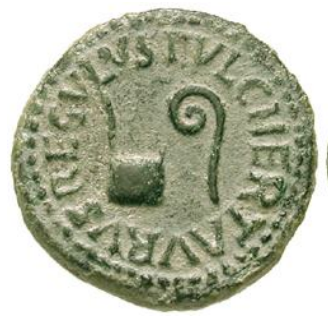

Figure 35. quadrans of Taurus et al., 8 B.C.

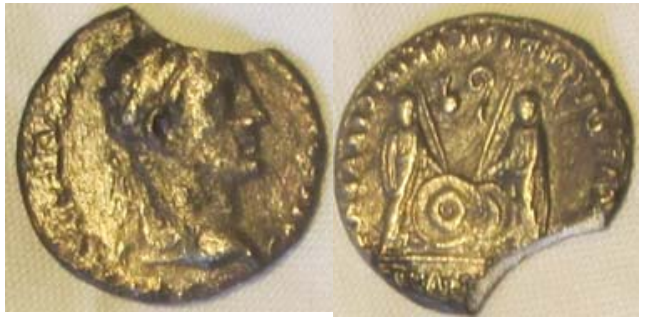

Figure 36. Denarius of Gaius and Lucius as principes 2 B.C.

The excessively dynastic atmosphere to which these coins contributed brought on dire consequences. A conspiracy formed against Augustus among the nobility. ${ }^{16}$ Thereafter, the Roman mint ceased to issue coins

16 The unlucky conspiracy of Iulus Antonius, Vell. 2.100.2-5; Sen. De Brev. 4.5; Dio 55.9.12-16. 
bearing religious imagery to promote him or his sons for priesthoods or to justify his regime. Only the modest lituus continued.

\section{The Re-use of Julius' Images by Later Emperors}

Of Tiberius, Caligula, and Claudius, only Claudius recycled an Augustan reverse (that of 16 B.C.), and not for himself, but when he inducted Nero as his heir into the top four religious colleges (see Figure 37). ${ }^{17}$ When Vespasian came to power, he avoided association with the odious Claudius and Nero to reach back to recycle Julius' 46 B.C. issue with simpulum, aspergillum, jug, and lituus to show his multiple priesthoods and his accession as Pontifex Maximus (see Figure 38). The idea that the emperor should hold multiple priesthoods was now an ingrained feature of monarchy. Vespasian's denarius closely resembles that of Julius, even copying most of the reverse legend, AUGUR PON MAX. For Vespasian, Julius was now a natural forefather in imperium with whom an ideological association in no way created an unwelcome connection, now that monarchy was entrenched. ${ }^{18}$ Of course, the meaning has changed, even if the image on the coinage looks the same. Julius had to assert himself against rivals; Vespasian had won the civil wars and was paramount. The coin is more a tribute to the victory of absolutism than a paean to Julius' memory. Nerva, Antoninus Pius, and Marcus Aurelius reused the same reverse in their own issues when they in turn became Pontifex Maximus as new emperors.
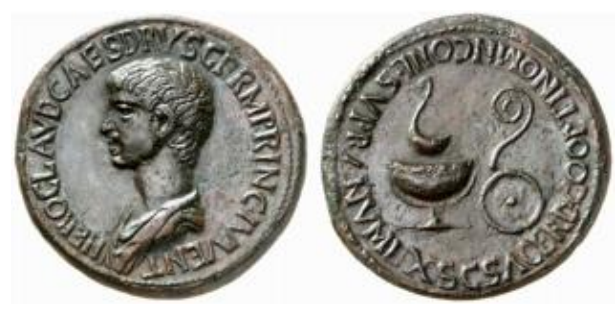

Figure 37. Nero denarius under Claudius, 52 A.D.

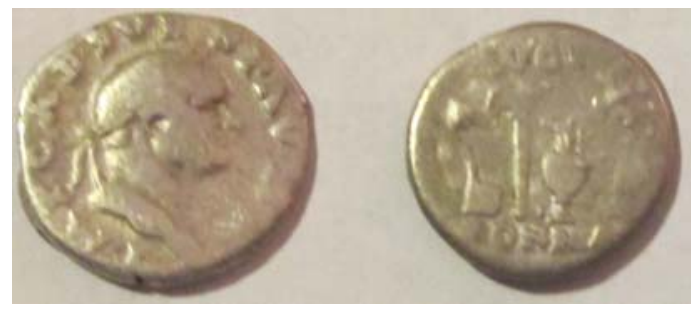

Figure 38. Vespasian denarius after Julius, 70 A.D.

\section{Conclusions}

While the use of religious implements on Republican coinage started out as a form of self advertisement, Julius expanded the practice to proclaim a holier than thou status over his rivals. During the 40s and 30s various imperatores borrowed his imagery to advance their own ambitions, usually loudly expressing loyalty to his memory to the public. Well into the Augustan regime, imagery from Julius continued to reappear from time to time on coinage, although its original context no longer had any practical value. An Augustan alternative did not endure, despite Claudius's favor. Subsequently, Vespasian recycled Julius's imagery to announce his accession as emperor and Pontifex Maximus because the Divine Julius was seen as a natural predecessor of the emperors. In this atmosphere, the emperor could directly vaunt his own holiness through the presence of multiple religious symbols on coinage, both for self-promotion and to discourage others from opposing the holder of secular and sacral power.

\footnotetext{
17 Tiberius and Caligula did not employ religious implements on their coinage to advertise their priesthoods. The closest parallels would be their coins declaring their elections as Pontifex Maximus, both of which bear Vesta (sometimes misidentified as Livia in the case of the Tiberian issue) and the words PONT MAX.

18 This is why Suetonius included a biography of Julius in The Twelve Caesars.
} 


\section{References}

Lewis, M. H. (1955). The official priests of Rome under the Julio-Claudians. Rome: American Academy.

Sear, D. (1995). The history and coinage of the Roman imperators 49-27 B.C. (190-191). London: Spink.

Stern, G. (2003). M. Aemilius Lepidus and the four flamines on the Ara Pacis Augustae. In A. A Donohue, C. C. Mattusch, \& A.

Brauer (Eds.), Common ground: Archaeology, art, science and the humanities, Acta of the XVI International Congress of Classical Archaeology (pp. 293-297), Cambridge, MA: Oxbow Monograph.

Stewart, R. (1997). The jug and lituus on Republican coin types: Ritual symbols and political power. Phoenix, 51, 107-189.

Szemlar, G. J. (1972). The priests of the Roman Republic. Brussels: Latomus.

Vangaard, J. H. (1988). The flamen: A study in the history and sociology of Roman religion. Copenhagen: Museum Tosculanum. Wallace-Hadrill, A. (1986). Image and authority in the coinage of Augustus. The Journal of Roman Studies, 76, 66-87. 